Михайлова А.М.

\title{
В.Г. Сахновский о театре А.Н. Островского. Постановка «Грозы» в Московском Драматическом театре
}

Аннотация: Статья посвящена исследованию интерпретации В.Г. Сахновским драматургии А.Н. Островского. Творческое наследие режиссера, театроведа и педагога Василия Григорьевича, до недавнего времени находившегося на периферии театральной науки, представляет собой весъма обширную культурную тему. Изучение теоретических работ Сахновского об Островском и выступлений режиссера на заседаниях театральной секции РАХН, а также анализ сценических опытов самого Сахновского не только расширяют наши представления о драматургии Островского на советской сцене, но и сообщают ряд важных характеристик режиссерского метода Сахновского. Объектом исследования является интерпретация В.Г. Сахновским драматургии А.Н. Островского. Стоит выделить несколько предметов исследования: работа В.Г. Сахновского «Театр А.Н. Островского», выступление Василия Григорьевича на обсуждении постановки Вс.Э. Мейерхольда «Лес», сценическая трактовка пьесы «Гроза» в Московском Драматическом театре. В рамках проведенного в статье исследования автор прибегал к контекстуальному, историко-культурному, сравнительному и театроведческому анализу. На основе проведенного исследования автор пришел к следующим заключениям: Сахновский в интерпретации творчества Островского придерживается линии Аполлона Григорьева, открывщем в драматурге поэта народной жизни, создавшего первый национальный русский театр. Анализ постановки «Грозы» и позиции Василия Григорьевича по отношению к сценическим опытам Мейерхольда открывает причины бедственного положения Сахновского в общественном и культурном контексте двадизатых.

Ключевъе слова: В.Г. Сахновский, А.Н. Островский, советский театр, режиссура, драматургия, творческий метод, В.Э. Мейерхольд, Московский драматический театр, интерпретация, театральная постановка.

Review: The article is devoted to studying Vasily Sakhnovsky's intepretation of Alexander Ostrovsky's playwriting. Artistic legacy of a theatre director, theorist and teacher Vasily Saknovsky who had been on the periphery of theatrical science until recently is a rather broad cultural issue. The research of theoretical works written by Sakhnovsky about Ostrovsky and his speeches made during meetings of the theatrical section of the Russian Academy of Sciences as well as analysis of Sakhnovsky's performances do not only extend our idea for Ostrovsky's playwriting but also reveal a number of important features of Sakhnovsky's directing method. The object of the research is Vasily Sakhnovsky's interpretation of Alexander Ostrovsky's plays. The following several subjects of the research should be stressed out: Vasily Sakhnovsky's work 'The Theatre of Alexander Ostrovsky', his speech devoted to the discussion of Vsevelod Meyerhold's play 'The Forest' and his theatrical interpretation of the play 'The Thunderstorm' at Moscow Drama Theatre. In the course of her research Mikhailova has used the contextual, historical-cultural, comparative and theatrical analysis. The researcher has made the following conclusions based on the results of the research: in his interpretation of Ostrovsky's plays, Sakhnovsky adopted the views of Apollon Grigoriev who saw Ostrovsky as the founder of the first national Russian theatre. Through analyzing Sakhnovsky's performance of 'The Thunderstorm' and his attitude to Meyerhold's theatrical experiments, the researcher reveals why Sakhnovsky was so poorly appreciated by the social and cultural communities of the 2O's.

Keywords: Interpretation, creative method, Vsevelod Meyerhold, dramaturgy, directing, soviet theatre, Alexander Ostrovsky, Vasily Sakhnovsky, Moscow Drama Theatre, theatrical performance. 
T ворческое наследие режиссера, театроведа, театрального критика и педагога Василия Григорьевича Сахновского (1886-1945) представляет собой большую культурную тему. Внимания заслуживают не только сценические работы Василия Григорьевича, но и ряд его теоретических трудов. Значительный вклад Сахновскогоисторика в историю отечественного театра составляют «Письмо к К.С.Станиславскому. Художественный театр и романтизм на сцене» (1917), «Театр А. Н. Островского» (1919), «Влияние театра Островского на русское сценическое искусство» (1923), статья «Мейерхольд», опубликованная во «Временнике РТО» (1924), «Мысли о режиссуре» (1947) и др. Вкупе со спектаклями и выступлениями В.Г. Сахновского на заседаниях театральной секции Академии художественных наук, труды Василия Григорьевича позволяют не только составить полный портрет Сахновского-режиссера, но и восстановить целостную картину развития отечественного театрального искусства.

Значительный исследовательский интерес для В.Г. Сахновского составляла фигура А.Н. Островского. Помимо вышеупомянутых работ, из-под пера Сахновского вышла статья «А.Н. Островский на сцене МХАТ» (1945), а также режиссёрские комментарии к пьесам А. Н. Островского «На всякого мудреца довольно простоты», «Бедность не порок», «Свои люди - сочтемся» и «Бешеные деньги». К сценическому воплощению драматургии Островского Василий Григорьевич обращался шесть раз. Первой постановкой стала «Гроза» в сезоне 1921-1922, затем последовали постановки пьес «Волки и овцы» (1927/1928), «Последняя жертва» (1934/1935), дважды «Бесприданница» (1932/1933 и 1937/1938) и «Трудовой хлеб» (1939/1940).

Отдельно стоит отметить, что «увлечение» Островским было симптоматичным для русской культуры конца 1910-х - 1920-х годов. Творчество Александра Николаевича обрело на советской сцене новую жизнь. Новая волна популярности драматургии А. Н. Островского пришлась именно на первое десятилетие советского театра. Все возрастающий интерес к драматургу, проявившийся чуть ли не во всех сферах культуры и искусства, можно объяснить многими факторами. Прежде всего, драматургия Островского в отсутствие подходящего репертуара (дореволюционная драматургия себя уже изжила, а современной советской пьесы еще не было) давала богатый, основанный на русской национальной почве материал для постановок. Отечественный театровед Е. Г. Холодов, подходивший к изучению Островского с единственно допустимых в советской науке позиций революционно-демократической публицистики Н. А. Добролюбова и Н. Г. Чернышевского, отмечал также, что Островский был нужен революционному народу. Не только и не столько из необходимости просвещения и образования рабоче-крестьянской аудитории, сколько по той причине, что Николай Александрович «открывал трудящемуся человеку огромный мир и помогал ему уяснить исторический смысл собственного революционного подвига» [14, с.3]. На сцене перед зрителем «представал тот самый мир насилия, который он разрушил; через рампу к нему неслась вековая мечта униженных и оскорбленных о справедливости, мечте, которую он претворил в жизнь» $[14$, c.3-4]. Островского хотели видеть и социальным поэтом, общественником, сатириком, разоблачителем темного царства, купцовсамодуров, и защитником униженных, слабых и бедных. Нельзя не вспомнить и лозунг А. В. Луначарского «Назад к Островскому!», выдвинутый им в статье «Об Александре Николаевиче Островском и по поводу его». Лозунг Анатолия Васильевича призывал к поиску компромисса: защиты старой классической культуры, на традицию которой должно было опереться будущее театральное возрождение, и утверждения здорового реализма, содержательного социально-психологического театра, понятного простому человеку в отличие от нарочитой гротескности, абстрактности и радикальности футуризма, биомеханизма и прочих «-измов».

И, конечно же, важным рубежным моментом в освоении Островского советским театром стало 100-летие со дня рождения великого драматурга в 1923 году, послужившее толчком, поводом для многочисленных обращений к Островскому. Перед фасадом Малого театра была совершена закладка памятника А.Н. Островскому, открытие которого состоялось спустя шесть лет (скульптор Андрей Николаевич Андреев, архитектор Иван Павлович Машков). В том же юбилейном году был завершен десятый том первого советского собрания сочинений Островского под редакцией Н.Н. Долгова (в 1923-1924 годах Борис Викторович Томашевский готовит к публикации 11ый том). Среди большого количества сборников и отдельных статей 1923 года, посвящен- 
ных Островскому, стоит назвать Юбилейный сборник, подготовленный Театральной секцией Российской Академии Художественных наук - «Творчество А.Н. Островского». В него вошли статьи Б.В. Варнеке («Островский и сценические исполнители»), А.А. Фомина («Черты романтизма у Островского», «Связь Островского и предшествующей драматической литературы»), П.А. Маркова («Морализм Островского») и В.Г. Сахновского («Влияние театра Островского на русское сценическое искусство»).

Четырьмя годами ранее вышла небольшая книга В.Г. Сахновского «Театр А. Н. Островского», вызвавшая бурную реакцию и множество споров. Действительно, приходится отмечать, что при всей остроте, глубине и значительности исследования, в некоторых местах работа Сахновского отличается непоследовательностью и противоречивостью. Остановимся же на тех моментах исследования, которые представляют, по нашему мнению, наибольшую ценность и значимость.

Важнейший пунктом в оценке Сахновским Островского является признание Александра Николаевича самобытным драматургом, создавшим первый национальный, подлинно русский театр. И, утверждая истоки творчества Островского в его «народности» (хотя сам Василий Григорьевич честно признается, что не может теоретически определить, что есть «народность»), Сахновский приводит читателя к осознанию «условности» театра Александра Николаевича. Произведения его, продолжает автор, не списаны с русской жизни, и мы, как читатели, не скрываем этого от себя: «Мы прочитываем в Островском искусством созданную, вечную для могущих зажечься от прекрасного, Россию» [9, с.8]. И сила театра Островского, по мнению Василия Григорьевича, «заключается в том, что он условен и потому сценичен и театрально выразим» [9, с.16]. Продолжим мысль Сахновского и заметим, что сценичность и театральная выразительность драм и комедий Островского обеспечена «универсализмом» его творчества. Это именно то качество драматургии Островского, которое относит ее к классике русского театра, не сходящей со сцены в течение более полутора веков. Это также дает ответ на вопрос о причинах повышенного интереса к творчеству Островского в 1920-е годы.

Сахновский выделяет две линии в литературе по отношению к изображению быта в произведениях. Первые - те, кто рисует лю- дей вообще, кого герои интересуют с общечеловеческой стороны, в них нет «устремленного тяжелого взгляда поэта на группу явлений или такие черты, которые давали бы материал народно-группового характера» [9, с.23]. Таковы, например, А.С. Пушкин, И.С. Тургенев, Г. Мопассан, И.В. Гете. К другой группе Василий Григорьевич относит О. Бальзака, Ч. Диккенса и А.Н. Островского. Эти писатели «видят, как по преимуществу в национальном проявляется всечеловеческое, и потому пытливо созерцают причудливую игру национальной индивидуальности» [9, с.24]. В их сочинениях читатель обнаруживает «целые пригоршни неописуемых драгоценностей в области быта» [9, с.20].

Василий Григорьевич дает удивительно образные определения «быта»: «ларец накопленного народом богатства» [9, с.20], «застывшая лава когда-то кипучей, вулканической природы личности» [9, с.21]. Сахновский очень глубоко понимает быт: «быт хранит все, укоренившиеся в данной среде и ставшие привычкой и необходимыми условиями жизни, приемы относиться к окружающему, к вещам и к людям; приемы относиться к себе, воспитанные семьей и средой, типовые, генеративные приемы думать и чувствовать» [9, с.20-21]. В быте находит отражение миросозерцание всего народа. В таком понимании, быт, действительно, становится «знаком бытия».

Сахновский фактически проводит прямую линию от Островского (в поздних сочинениях которого, действительно, чувствуется это устремление к поэтике недосказанности, подтекста, невыраженного конфликта) к Чехову: «нужно быть на редкость невосприимчивым читателем, - пишет Сахновский, - чтобы не заметить, что люди Островского живут часто не тем, о чем говорят и что на этом его пестром житейском базаре не только торгуют и прицениваются, но маются тою настоящей всем людям свойственной горькой жизнью, которая привлекает к себе читателей всего мира» [9, c.27]. Так и просится вслед за словами Сахновского цитата из Чехова: «...и мы узнаем, зачем мы живем, зачем страдаем... Если бы знать, если бы знать!» [15, с.177].

Романтизм Островского Василий Григорьевич ведет из его «поэтичности», ведь в лучших своих созданиях Александр Николаевич заявил себя именно поэтом жизни, а не ее обличителем и карателем. С помощью «героев человеческой незначительности» и из не- 
значительных происшествиях у Островского, по мнению Сахновского, складывается, как из песчинок, жизнь.

Островский берет «натуры крутые, сырые, неразработанные культурой» $[9$, с.6о] и показывает, как в них теплится искра Божия, Божий свет, «что в их душе живет то же общечеловеческое, всечеловеческое начало, та же борьба добра и зла, которая определяет содержание жизни всех народов и всех веков» $[9$, с.6о].

Однако затем от «поэтичности» Островского Сахновский переходит к описанию «желтенькой жизни» героев его пьес. В своем исследовании Василий Григорьевич идет парадоксальным путем: от утверждения универсальности, всеохватности творчества Островского автор идет к сужению границ, обращаясь к темной, страшной стороне комедий и драм Александра Николаевича. Причина, заставляющая Василия Григорьевича в своей работе двигаться именно в таком направлении - это мучающий автора вопрос: «Не такова ли жизнь в нашем грубом обиходе? Не справедлив ли драматург?» [9, с.89].

И Сахновский принимается за детальное описание этой «желтенькой», «убогой», «грошовой» жизни, описывая и типологизируя характеры и нравы героев Островского. И страшно в них «нестрашное»: безыдейность, жалкость, скопидомность, прибытчество, глубокое равнодушие ко всему, что только не касается насущных потребностей. Но «надо всеми, заключает Сахновский, тяготеет, словно рок, нечто еще более страшное, - это неизбежность жить по обыкновению, по обычаю, по заведенному однажды порядку» [9, с.178].

И, повергнув читателя в пучину «темного царства» (в статье Сахновского рядом с выдержками из сочинений А. Григорьева находится место и для цитирования Н. А. Добролюбова), Сахновский предлагает читателю самому найти ответ на поставленный вопрос: «Перед нами развернуты картины жизни, и читатель остается перед ними, обязанный сам решить: такова ли она, как ее нарисовал художник, или только Островский видел ее таковой» $[9$, с.190] ...

Неоднозначными были оценки, вынесенные сочинению Василия Григорьевича. Так, исследователь Николай Павлович Кашин, долгие годы занимавшийся текстологией пьес Островского, в своем отзыве [4, с.15] назвал труд Сахновского интересной, знаменательной новинкой, представляющей после работ Жоржа Патуйе (французского литературоведа, перу которого принадлежат труды «Русский театр нравов с его зарождения до Островского» и «Островский и его театр русских нравов») новый этап в оценке Островского. Но при этом, рецензент отметил, что Сахновский многое «надстроил», «приписал» то, чего у Островского нет, и отнес на счет драматурга то, что тот вложил в уста своих героев. Федор Степун характеризовал работу Василия Григорьевича как «несколько хаотичную, местами косноязычную, так же недоработанную, недонесенную, как и его постановки, но безусловно артистичную и во многом поразительно острую» [12, с.4]. Марков спустя годы в режиссерском портрете Сахновского писал: «книга “Театр А. Н. Островского” вводила в мир драматурга со страстью исследователя и эмоциональностью художника» [5, с.533].

В добавление к вышеперечисленным характеристикам, стоит заключить, что статья Василия Григорьевича, несмотря на ее субъективный характер, выявляет ряд важнейших положений, открывающих творчество Островского с новой, а иначе говоря, с «хорошо забытой старой» стороны. «Театр А. Н. Островского» по праву стоит отнести к ряду работ начала века, продолжающих в критической литературе линию Аполлона Григорьева. К этому «направлению», противостоящему революционно-демократической публицистике во главе с Н.А. Добролюбовым, можно причислить и критиков XIX века А. Дружинина и Н. Страхова, и исследователей начала XX века - А.Р. Кугеля, Б.В. Варнеке, П.А. Маркова, П.В. Анненкова, Н.П. Кашина. В их трудах А.Н. Островский предстает не в качестве драматурга-бытописателя и обличителя самодуров и «темного царства», а как поэт народной жизни. Открывается сущностно-религиозное, национальное, общечеловеческое поэтики Островского; на первый план выдвигаются категории быта как проявления миросозерцания народа, категории универсальности и онтологичности.

Вероятно, появление в отечественной филологии и театроведении подобных статей, явилось основной «внутренней» причиной популярности драматурга в 1910-1920-х годах. И, пожалуй, именно эта, внутренняя причина явилось толчком, заставившим режиссеров обратиться к драматургии Островского. Возрожденное и освобожденное из плена «темного царства» творчество Островского требовало соответствующего нового сценического 
воплощения. Не внешнее, злободневное, сатирическое могло привлечь мастеров сцены, а вечное, народное, религиозное, поэтическое, универсальное. В некоторой степени эту причину можно назвать бессознательной, уподобить ее «подводному течению», продолжавшему движение по инерции и в первые годы советской власти. Вновь открытые основы, утверждаемые драматургией Островского, были той исконно русской «опорой», которая к началу века была окончательно утрачена, но обрести которую было необходимо. Но все это касалось отвлеченных философских идей, революция же монтировала и режиссировала по-своему. И на сцены театров вернулся Островский-сатирик.

Неоднократно интерпретации классики на советской сцене становились предметом оживленных дискуссий. Но более всего современникам запомнился спор, разгоревшийся на обсуждении спектакля «Лес» в феврале 1924 года. К сожалению, стенограмма этого заседания не сохранилась. Однако опубликованный в «Еженедельнике Академических театров» отчет о заседании под названием «Вариации Островского» и материалы диспута, продолжившегося в ТИМе, дают представление о характере дискуссии в РАХН.

Важно упомянуть, что спор, разгоревшийся вокруг мейерхольдовского «Леса», был спором глобальным, это была саморефлексия революционного театра. Раскрепощение нового времени стимулировало и развитие театрального мышления и языка, и поиск новых подходов к тексту, и опыты введения политических аллюзий и проч. Все это и многое другое входило в круг проблем и тем дискуссии о «Лесе», которая в действительности была дискуссией о путях развития революционного театра. И тем показательнее, что Мейерхольд представил пьесу прошлого столетия через призму 1920х годов XX века. Ведь Россия двадцатых годов была совсем не похожа на Россию середины века девятнадцатого, - это была изуродованная, искаженная, абсурдистская страна.

Остановимся на материалах этой дискуссии несколько подробнее ввиду того, что в них, помимо замечаний Василия Григорьевича о возможностях интерпретации А.Н. Островского на советской сцене и о новых приемах Мейерхольда, можно обнаружить свидетельства о взглядах Сахновского на современный театральный процесс, зрительскую аудиторию и о положении Василия Григорьевича по отношению к обоим.
В своей речи Сахновский настаивал на том, что в «Лесе» Мейерхольда зритель имеет дело не с сочинением А.Н. Островского, а лишь с вариациями на его пьесу. Во-первых, разделив весь текст пьесы на 33 эпизода, Мейерхольд значительно изменил архитектонику пьесы и выдвинул на первый план мотивы, которых нет у драматурга. Во-вторых, как отмечает Василий Григорьевич, в мейерхольдовском спектакле совершена подмена темы: «в тексте Мейерхольда существует глумление над несуществующим» [11, с.208]. Сахновский приводит здесь в пример сцену педикюра Гурмыжской, расстройство желудка Аркашки, пародию на крестный ход и молебен об урожае в прологе, которых не было в тексте пьесы.

В работе «Театр А. Н. Островского» 1919 года Сахновский писал: «Как это показательно, что для Островского нравственный мир людей, среди которых живут трепетные, непонятные сердца, взыскующие к Красоте и Добру души, - это лес. Какое хорошее название! Какой замечательный образ рисуется в душе читателя, при произнесении слова Лес» [9, c.132]. Для Василия Григорьевича была важна семантика названия пьесы, связанная с образом леса, который, с одной стороны, связан с природным, поэтическим началом, а с другой стороны, может служить метафорой чего-то глухого, дремучего и непролазного. Во время же просмотра спектакля Мейерхольда у Сахновского возникло впечатление, что пьеса происходит не на фоне Леса, не на фоне глухой России 1870-ых годов, а на фоне дачной карусели. Образец внешнего оформления спектакля Сахновский находил в стиле сатирического журнала «Крокодил», газеты атеистической направленности «Безбожник» и рекламы папирос, парфюмерии, шипучих вод и квасов. В итоге: «обман в корне всего предприятия» [8, с. 359].

Хотя Сахновский и отдавал должное смелому новаторству режиссера, хоть и признавал, что все сделанное Всеволодом Эмильевичем в спектакле «Лес» по-новому ярко, талантливо и завораживающе, но все же обращал внимание на то, что все это было сделано «нарочно». Нарочитость, намеренность заключалась в гениальном уловлении требований той публики, которая посещает Театр Мейерхольда. Режиссер, по убеждению Сахновского, «чрезвычайно ловко пустил крючок, на который подловил залу» [7, с.357]. Всеволод Эмильевич, как считает Сахновский, избрал ложный путь: изумительно зная Островско- 
го и прекрасно умея его раскрывать, Мейерхольд, вместо того, чтобы взять свое «чувство Островского» и «перелить его в надлежащую форму», «воспользовался приемами карикатурного порядка и рассчитал на соответствующую восприимчивость мало ознакомленной с различными моментами театра публики, которая посещает театр. <...> люди, идущие сюда, могут быть в том, что здесь показывают, недостаточно осведомленными, они нуждаются в серьезном вскрытии вещи, как она дана» [11, с.210].

Различия в восприятии зрителя Мейерхольдом и Сахновским определили раскол, в результате которого режиссеры оказались по разные стороны одного театрального процесса. В своем ответном слове Всеволод Эмильевич, подводя всю речь к указанию на классовые различия зрительской аудитории и В.Г. Сахновского, подчеркнул, что ТИМ к каждой новой постановке подходит с твердым знанием, «что это новое строение может понять именно только современный зал, зал рабочих, крестьян и красноармейцев» [11, c.216]. Как ни горько читать предъявляемые Мейерхольдом Сахновскому обвинения в его консервативности, реакционности, классовой чуждости, в обвинениях этих есть значительная доля истины.

В этой новой жизни, в этом новом времени Василий Григорьевич не находил опоры для своего искусства. Прошлое же ушло безвозвратно. И Сахновский остался над разверстой пропастью между днем вчерашним и днем сегодняшним. Показательным в этом отношении оказалась и постановка Василием Григорьевичем «Грозы» в 1922 году.

Спектакль Сахновского не только пришелся на пору пиршества экспериментального театрального духа начала двадцатых, но и вошел в ряд многочисленных обращений к драме А. Н. Островского тех лет. Сценическая история «Грозы» в отечественном театре 1910-20-х годов, действительно, богата и значительна. За годы с 1916 по 1924 насчитывается по меньшей мере пять постановок драмы А. Н. Островского «Гроза»: Вс. Мейерхольда (1916, Александринский театр), Б. А. Фердинандова (1921, Опытно-героический театр), В. Г. Сахновского (Московский Драматический театр), И. Я. Судакова (1923, Вторая студия Художественного театра), А. Я. Таирова (1924) и др. Какое место заняла «Гроза» Василия Григорьевича по отношению к новейшим театральным опытам и методам интер- претации А.Н. Островского, станет очевидно из сопоставления замыслов постановки и их реализации на сцене.

Пьеса А.Н. Островского ставит перед создателями спектакля ряд сложнейших задач: определение жанровой природы «Грозы» (как бытописательной, психологической драмы, трагедии, мистерии); сценическое изображение быта; поиск верного тона, ритма, темпа в работе над сценической речью. Практическое воплощение замыслов постановки демонстрировало, помимо прочего, наличие разработанного режиссерского метода. Зачастую «Гроза» предваряла будущие открытия или обнаруживала несовершенство применяемой системы, ее «неуниверсальность». В контексте 1920-ых годов приверженность одной из двух линий в интерпретации Островского и соответствующее сценическое выражение той или иной трактовки выходит за пределы интерпретации исключительно творчества Островского и распространяется на вопросы идеологии и режиссерской методологии.

В. Г. Сахновский подробно и образно передал основные замыслы постановки в «Режиссерских заметках о “Грозе” Островского», впервые опубликованных в третьем номере журнала «Жизнь» в 1922 году, а позднее вошедших в недавно изданное в альманахе Мнемозина «Театральное скитальчество». В интерпретации Василия Григорьевича единую ткань пьесы создают одна на другую наложенные две «пелены». Таким образом, Сахновский в прочтении Островского идет от основных теоретических принципов романтическо-философского театра, отвечающих романтической концепции двоемирия: проявление значительности в незначительном, символического в обыденном, абсолютного в реальном.

Нижняя пелена - это «с величайшим знанием человеческого сердца» [10, с.208] написанная обыкновенная история русского семейства в уездном городе, в которую вписаны старинные обычаи, обстановка и уклад жизни в купеческой среде. Верхняя пелена символическая, по которой, по выражению Сахновского, «затканы знаки грозы и греха» [10, с.208]. Это «стихийная жизнь природы, любви, самовластья, безудержа, богобоязни» [10, с.208], дремлющая в незначительных и неприглядных жителях города Калинова. Bce, что подспудно существовало в этих людях будто сгущено в образе грозы и предвещающих ее ударах грома. В верхней пелене «нет 
тишины и созерцательности бытописца» [10, c.209], в ней «тревога и разметанность в поведении лиц, совершающих мистериальную службу, мистериальную драму» [10, с.209].

Ориентация на мистерию позволяет судить о масштабах обобщения в толковании Сахновским драмы А. Н. Островского. В соответствии с этим, можно составить представление о художественном времени и пространстве спектакля, о решении центрального образа драмы - Катерины, о значительности, которую придает Василий Григорьевич случившейся в городе Калинове истории.

«Гроза», какою видит ее Сахновский, - это подлинно русская трагедия, мистерия любви. Причем любви, «лежащей в ином плане бытия», любви, несущей «роковое семя гибели в этом "мире” " [1]. В своей интерпретации Василий Григорьевич выводит на первый план категории универсализма и онтологччности поэтики Островского. И хронотоп «Грозы» Островского-Сахновского, с одной стороны, отражает непреходящую суть бытия в изменяющихся формах, постоянство в повторяемости, с другой же - подразумевает мистериальное трехуровневое вертикальное пространство (действие спектакля происходит исключительно на Земле, населенной грешными людьми, но земное пространство наполнено символами-напоминаниями об Аде и Рае - таковы, например, сны Катерины и ее воспоминания о прошлой жизни).

История грехопадения Катерины в понимании Сахновского носит характер неизбежности, «ибо грех и преступления висят над человеком, ибо так хочет Бог, ибо такова проблема мира» [10, с.209]. Все происходящее - мистериальная служба, ритуальное принесение жертвы, без которой немыслима человеческая жизнь. Жизнь, «которую однажды изживая, причащаемся тайн вечной свободы и духовного бессмертия» [10, с.209].

«Страстная и чистая, всегда девственная и в страсти» [10, с.214] Катерина, какой ее видел Василий Григорьевич, восходила в его представлении к образу боттичеллиевой Мадонны и Моны Лизы да Винчи. Впрочем, костюм Катерины был далек от ренессансного культа красоты и жизни и приближался в своей образности к иконописи: высокий кокошник в виде цилиндрической шапки, покрытый светлым платком, туго заколотым под подбородком, напоминал апостольник, головной убор православных монахинь. Но русской Мадоннъ в Катерине Поповой критика разгля- деть не смогла. Молодая Кабанова, какой она предстала критикам, была «интеллигентной женщиной, воспитанной на стихотворениях Блока, читавшей Бодлера и Оскара Уайльда» [13], односторонне истеричной и замкнутой в кругу личной психологической драмы.

В поисках основного тона исполнения «Грозы» Василий Григорьевич, казалось, должен был идти по всегда интересовавшей его линии поиска мелодии, «ритмически-тонкой музыки» $[6$, с.28] произведения. И в своих режиссерских заметках Сахновский, действительно, смену настроений от одного действия к другому передавал через определения музыкальных темпов и метафоры света-тьмы. Но проблема произнесения текста была в заметках обойдена молчанием.

Вероятно, обеспечить некоторое стилистическое единство в сценическом исполнении «Грозы» были призваны два типа мизансцен, найденные Сахновским в соответствии с двумя «пеленами» единой ткани пьесы. В первом варианте мизансцен актеры одиноко предстояли зрителю, оторванные друг от друга, резко выделявшиеся в своих костюмах и головных уборах на фоне декораций. В этом замысле Сахновского было и молитвенное предстояние Богу, и иконопись с предстоящими святым ликам фигурами. Павел Александрович Марков в режиссерском портрете Василия Григорьевича прекрасно передал впечатление, рождаемое подобными мизансценами в последнем акте «Грозы»: «Действие развертывалось на фоне ночной невидимой Волги, на высоком берегу которой бродили потерявшие самих себя и друг друга люди. Не о «некоммуникабельности» говорила эта сцена, а о тщетных поисках человеческого в человеке. Сцена шла тоскливо, тревожно, и ритм то появляющейся, то исчезающей надежды пронизывал ее. Монолог Катерины - Попова произносила его почти без интонаций, сохраняя (она сидела на скамейке) одну и ту же смятенную, раздавленную позу, - был наполнен горечью открывшегося ей познания жизни, после которого нет иного выхода, как смерть. И мелькающие во тьме фонари, и впервые обнаруженные у Игоря Ильинского в роли Тихона человечность и столь же горькое, как и у Катерины, познание жизни превращали эту картину в одно из лучших разрешений «Грозы», которые я когда-либо видел» [5, с.533-534].

Другой ряд мизансцен - «лицом к лицу» - «родился, - как отмечал Сахновский, - из 
глубочайшей интимности тех чувств, которые зарождали в двойных сценах лица один в другом» $[10$, c.212] (сцена второго акта Катерины и Варвары, сцена третьего акта Кулигина и Бориса, сцена пятого акта Кулигина и Тихона, Бориса и Катерины). В этих мизансценах лицом к лицу, с пронзающим друг друга взглядом, на грани интимности и жестокости двое «соприкасались духовно» [10, с.212].

Однако, по замечаниям критиков, единства стиля исполнения актерам добиться так и не удалось, поскольку не найдена была Сахновским однообразная стилистика произнесения текста «Грозы». Если Михаил Лишин и Мария Рутц давали в образах Кудряша и Варвары привычную трактовку Островского в духе спектаклей Малого театра, то Максим Штраух, в создании своего Дикого шел, как показалось критике, от эскиза Малютина: «в его внешности, костюме, гриме, рыке, шуме, приплясывании все декоративно, преувеличено, все подчеркнуто и стилизовано» [12, с.4]. Таким образом, образовались два полюса постановки: консервативный, никак не связанный ни с интерпретацией пьесы Сахновского, ни с декорациями Малютина, и революционный, предвосхищавший по своей сути гротески мейерхольдовского «Леса» и «Горячего сердца» Художественного театра. Между двумя полюсами оказывалась игравшая «с приближением к Малютину» Рутц, в Варваре которой была «гульливость и зазыв, девичья воля и вольница» [12, с.4]. Необаятельный Кулигин Макса Терешковича был и вовсе дан вне соотнесения с пьесой Островского: в нем не было «обязательного в Кулигине "благорастворения воздухов” и <...> гуманизма, как душевной категории» $[12$, с.4]. Сведенные вместе различные манеры исполнения расшатывали единство спектакля.

И все же нашлась самая совершенная фигура спектакля, в которой органично оказались связаны «мечты Сахновского и живопись Малютина с речью и повадкой Малого театра» [12, c.5]. Таким в глазах критика Степуна предстал Тихон в исполнении Игоря Владимировича Ильинского. «Резкое сочетание настоящего комического дарования и углубленного драматического переживания» [12, с.5] в Ильинском определили путь раскрытия образа Тихона. Введя во внешнюю характеристику своего персонажа некоторые смелые жесты, на которых лежала тень эксцентрических выходок Брюно из мейерхольдовского «Великодушного рогоносца» (рогатка мизинца и указательного пальца, которой «рассуждает» Тихон; «переминание с ноги на ногу, превращающееся в конце концов в быстрый, плясовой комический "передрыг” колен» [12, с.5]), Ильинский не загромоздил этими резкостями «слабой, жалкой, пьяненькой, но нежной, подлинно человеческой души Тихона» [12, с.5].

Художником в спектакле Сахновского был Иван Андреевич Малютин, в начале 1920-ых один из художников «Окон сатиры РОСТа» и карикатурист журналов «Смехач», «Заноза», «Безбожник у станка» и проч. Сахновский видел оформление «Грозы» в условных декорациях, «однако не претендующих ни в коем случае на беспредметность и оторванность от натуры» [10, с.212]. Василий Григорьевич находил образец искомого отношения человека к вещам, природе и жилью в художественной манере Поля Сезанна.

$\mathrm{He}$ постимпрессионистические в духе Сезанна, а скорее, полуэкспрессионистические декорации в привычной для И.А. Малютина манере были призваны стать декоративным выражением принципа «быта, доведенного до символа». Открывала спектакль тихая, светлая сцена на бульваре, на высоком берегу Волги, на фоне раскидистых деревьев и виднеющейся вдали церкви. Затем по мере нарастания беспокойства и тревоги к концу акта сцена затемнялась, и действие переходило в дом Кабановых: «тревога вползла в эти низкие сводчатые комнаты» [10, с.210]. Малютин изобразил каменную комнату с будто давящими сводами потолка, с «чудовищными и вовсе не близкими душе, не проливающими бальзам на раны сердца и совести» [10, с.210] иконами на стенах. В этой аскетичной, неуютной обстановке Сахновский предполагал передать «чин монастыря», царивший в доме Кабанихи. Но критика, оценившая пейзаж 1-го и 4-го действия и увидевшая в его «линиях и красках сущность быта Островского - крепкого, мрачного, заросшего до беспросветности, уродливого, искрюченного, как шупальцы спрута» [3], узрела в декорациях второго действия лишь несоблюдение историко-бытовых деталей: «Но в какую незадачливую минуту комната в доме Кабанихи, конечно, деревянном, нарисовалась ему сводчатым, каменным, монастырским подвалом?» [3].

Судя по критическим отзывам, весь грандиозный замысел Сахновского на сцене удалось воплотить лишь отчасти. Вместо народной трагедии и мистериальной драмы критики 
увидели только «личную психодраму героев пьесы» [13], которых режиссер сделал якобы неврастениками-интеллигентами, или вовсе «Грозу» по Арцыбашеву или Ведекинду. Отмечая, что постановка Сахновского была попыткой нетрафаретного толкования творчества Островского, одни критики по-прежнему требовали выявления «ужаса духовного и экономического рабства, невежества, преступности и хамства царской помещичье-кулацкой России и трагических мучений связанного народного духа» [13]. Другие же, напротив, отмечали, что невыявленной осталась мистическая сущность трагедии.

Пожалуй, единственным, за исключением П.А.Маркова, кто смог оценить значительность постановки «Грозы» Сахновского и максимально точно угадать его замысел, был Ф.Степун. Значение спектакля критик видел «в оправдании «Грозы», как подлинной трагедии» $[12$, c.5]. Степун почувствовал внеземную природу любви, с которой, прежде всего, был связан образ Катерины, любви неизбежной и губительной, которой Василий Григорьевич стремился наполнить спектакль: Катерина, «полюбившая, с самого начала обреченная. С самого начала над ней смерть только потому, что у нее в сердце любовь, неизвестно, как и когда пришедшая, любовь безродная, абсолютная, испепеляющая земную жизнь» $[12$, с.5].

Тем не менее, и Федор Августович отметил симптоматичное в постановке Сахновского противоречие формы и «духа». Незаконченность, незавершенность формы спектакля отнюдь не способствовала проникновению зрителя в глубокое духовное содержание произведения. «Многое звучало внутреннему уху своеобразно и глубоко, писал Ф.Степун, - но ничего не принималось глазом и ухом, как действительно сделанное, ультимативно воплощенное, окончательно сработанное» $[12$, c.4]. Спектакли Василия Сахновского в большей степени слышиались, подобно музыке, и чувствовались зрителями, нежели смотрелисъ; в них постигали суть, восхищались атмосферой и настроением, но не могли смириться с вечно ускользающей, дразнящей формой. Однако для самого Сахновского, для которого пространство театра всегда было местом священнодействия, роковое противоречие оказывалось принципом, стоящим в центре его режиссерской манеры. «Несносно ощущать в спектакле завершенность, - утверждал режиссер. - Прелесть - в покрыва- ющем искусство флере неясности, манящей зыби дрожащих далей, тут же в каждой точке, которую почти ощутил, которой коснулся и не касаешься, потому что она не действительна, но действительней всяческой материальности» $[10,250]$. Подобная грань незавершенности позволяла, по мнению Сахновского, «дотворить», зная основоположение художника. Этот принцип корнями своими уходит в эстетику романтизма, и отзываясь, рифмуясь в символизме, возрождается в неоромантическом театре Василия Григорьевича Сахновского.

И с сожалением приходится признавать, что оценка, вынесенная Эммануилом Мартыновичем Бескиным в одной из самых язвительных рецензий на «Грозу» 1922 года, отразила реальное положение Сахновского в социально-историческом и культурном контексте тех лет: «Все несчастие и культурного, и умного, и образованного Сахновского - он застыл в подержанном “модерн”... <...> От грохота и шума современности он ушел в “кабинет” и изучает жизнь по документам “Союза художников” и “Мира искусства”. И ему действительно, кажется, что он “переоценивает”, что он “буйствует”, что он несмотря ни на что, вопреки всем объективным условиям, продолжает творить новые мессы. Храм и месса Сахновского давно повержены. [2, с.16] <..> такой эклектизм, такое безпринципное эстетствование, a, главное, такой отрыв и от темпа и ритма “сегодня" и, конечно, от самого Островского . <...> Все это кабинетная “магия” литературничающей режиссуры. Все это лишено смелых широких производственнотеатральных подходов наших дней. А жаль и работы потрачено много, и Сахновский все же Сахновский, и Островский все же Островский и “Гроза" такой клад сценических возможностей» $[2$, с.18].

Василию Григорьевичу Сахновскому как человеку духовному, мыслящему и нравственному, всеми помыслами своими устремленному к вечному абсолюту, мучительно трудно было вписаться в новое время. И дальнейшая судьба этого последнего романтика была драматична. Но в каждый из моментов своего нелегкого пути Василий Григорьевич свято верил в возможность духовного преображения действительной жизни, в идеалы гуманизма и сохранение культурной традиции. И это сегодня особо выделяет его из ряда художников, которые с радостью и восторгом пошли служить дьявольскому режиму. 


\section{Библиография:}

1. Бердяев Н.А. Смысл творчества // Электронная библиотека русской религиозно-философской и художественной литературы «ВБхи». - Режим доступа: http://ww.vehi.net/berdyaev/tvorch/09.html, свободный.

2. Бескин Э.М. «Гроза» по Сахновскому // Театральная Москва. М., 1922. № 35. С. 16.

3. «Гроза». Постановка В. Г. Сахновского в Московском драматическом театре. Рецензии // Музей МХАТ. Фонд В. Г. Сахновского. № 8242.

4. Кашин Н. В.Г. Сахновский «Театр А.Н.Островского»// Вестник театра. М., 1920. №74. С. 15.

5. Марков П. А. О Василии Григорьевиче Сахновском // О театре: В 4 т. М., 1977. Т. 4. С. 526-539.

6. Мейерхольд Вс.Э. «Гроза». К возобновлению «Грозы» А. Н. Островского на сцене Александринского театра. Речь режиссера к актерам // В.Э.Мейерхольд; сост., ред. текстов и коммент. А.В.Февральского. - М.: Искусство, 1968. Ч. 1. С.285-293.

7. Сахновский В.Г. Вариация Островского // Мнемозина: Документы и факты из истории отечественного театра XX века. М., 2009. Вып. 4. С. 356-358.

8. Сахновский В.Г. О Мейерхольде. Отдельные наброски // Мнемозина: Документы и факты из истории отечественного театра ХХ века. М., 2009. Вып. 4. С. 358-359.

9. Сахновский В.Г. Театр Островского / В. Г. Сахновский - М., 1919. - 192 с.

10. Сахновский В.Г. Театральное скитальчество // Мнемозина: Документы и факты из истории отечественного театра ХХ века. М., 2009. Вып. 4. С. 180-254.

11. Стенограмма диспута в Театре имени Вс. Мейерхольда о постановке комедии А. Н. Островского «Лес» // Советский театр. Документы и материалы. 1921 - 1926 / Отв. ред. тома А. Я. Трабский. - Л. , 1975. - С. $207-217$.

12. Степун Ф. «Гроза» на сцене Московского Драматического театра // Экран. Вестник театра, искусства, кино, спорта. М., 1922. - № 30 (25 апреля 1922). - С.4-5.

13. Херсонский Х. «Гроза» в Московском драматическом театре // Известия ВЦИКа. М., 1922. (14 октября) // Музей МХАТ. Фонд В. Г. Сахновского. № 8242.

14. Холодов Е.Г. А.Н. Островский на советской сцене // Методические материалы в помощь мастерам сцены. Кабинет драматических театров. М., 1979. 117 с.

15. Чехов А.П. Три сестры // Чехов А.П. Пьесы. М., 2003. С. 177.

\section{References (transliterated):}

1. Berdyaev N.A. Smysl tvorchestva // Elektronnaya biblioteka russkoi religiozno-filosofskoi i khudozhestvennoi literatury «Vłkhi». - Rezhim dostupa: http://www.vehi.net/berdyaev/tvorch/09.html, svobodnyi.

2. Beskin E.M. «Groza» po Sakhnovskomu // Teatral’naya Moskva. M., 1922. № 35. S. 16.

3. «Groza». Postanovka V. G. Sakhnovskogo v Moskovskom dramaticheskom teatre. Retsenzii // Muzei MKhAT. Fond V. G. Sakhnovskogo. № 8242.

4. Kashin N. V.G. Sakhnovskii «Teatr A.N.Ostrovskogo»// Vestnik teatra. M., 1920. №74. S. 15.

5. Markov P. A. O Vasilii Grigor'eviche Sakhnovskom // O teatre: V 4 t. M., 1977. T. 4. S. 526-539.

6. Meierkhol'd Vs.E. «Groza». K vozobnovleniyu «Grozy» A. N. Ostrovskogo na stsene Aleksandrinskogo teatra. Rech' rezhissera k akteram // V.E.Meierkhol'd; sost., red. tekstov i komment. A.V.Fevral'skogo. - M. : Iskusstvo, 1968. Ch. 1. S. 285-293.

7. Sakhnovskii V.G. Variatsiya Ostrovskogo // Mnemozina: Dokumenty i fakty iz istorii otechestvennogo teatra XX veka. M., 2009. Vyp. 4. S. 356-358.

8. Sakhnovskii V.G. O Meierkhol'de. Otdel'nye nabroski // Mnemozina: Dokumenty i fakty iz istorii otechestvennogo teatra XX veka. M., 2009. Vyp. 4. S. 358-359.

9. Sakhnovskii V.G. Teatr Ostrovskogo / V. G. Sakhnovskii - M., 1919. - 192 s.

10. Sakhnovskii V.G. Teatral'noe skital'chestvo // Mnemozina: Dokumenty i fakty iz istorii otechestvennogo teatra XX veka. M., 2009. Vyp. 4. S. 180-254.

11. Stepun F. «Groza» na stsene Moskovskogo Dramaticheskogo teatra // Ekran. Vestnik teatra, iskusstva, kino, sporta. M., 1922. - № 30 (25 aprelya 1922). - S.4-5.

12. Khersonskii Kh. «Groza» v Moskovskom dramaticheskom teatre // Izvestiya VTsIKa. M., 1922. (14 oktyabrya) // Muzei MKhAT. Fond V. G. Sakhnovskogo. № 8242.

13. Kholodov E.G. A.N. Ostrovskii na sovetskoi stsene // Metodicheskie materialy v pomoshch' masteram stseny. Kabinet dramaticheskikh teatrov. M., 1979. 117 s.

14. Chekhov A.P. Tri sestry // Chekhov A.P. P'esy. M., 2003. S. 177. 